\author{
Review Article
}

\title{
AN OVERVIEW ON HITOPADESA VAIDYAKA
}

\section{Ujitha Kuttan $\mathrm{K}^{1 *}$, Braivin Camly $\mathbf{R}^{2}$}

${ }^{*}$ MD Scholar, ${ }^{2}$ Associate Professor, Department of Samhita Samskrita and Siddhanta, Govt. Ayurveda College, Thiruvananthapuram, Kerala, India.

\begin{tabular}{l}
\hline Article info \\
\hline Article History: \\
Received: 02-11-2021 \\
Revised: 28-11-2021 \\
Accepted: 06-12-2021 \\
\hline KEYWORDS: \\
Hitopadesa, \\
Vaidyakasarasamgraha, \\
Nadi pareeksha, \\
Ashtasthana pareeksha, \\
Sreekanthasuri.
\end{tabular}

Sreekanthasuri.

\begin{abstract}
Ayurveda, the science of life is dated back to thousands of years. In ancient times the knowledge of this system were passed orally from teachers to students. In course of time scholars began to record their knowledge in the form of treatises like Charaka Samhita, Susruta Samhita etc. Later many Acharyas composed their own treatises on the basis of knowledge they acquired as well as their own observations and experiences. Madhava Nidana, Sarangadhara Samhita, Bhavaprakasa, Kasyapa Samhita etc., are such contributions by various scholars. The ancient knowledge is updating by new physicians through the observations they made in relation with changes in Kala (time), Desa (place), availability of medicines, newly emerging diseases etc. So it is necessary to explore such treasures of knowledge.

Hitopadesa vaidyaka is a work on Ayurveda which gives emphasis on the diagnosis of disease as well as treatment through simple medicinal formulations. The book starts with Ashtasthana pareeksha where Nadi pareeksha is given utmost importance and provides description of Jvara etc., diseases with brief description on Lakshana (clinical features) and detailed description on Chikitsa (treatment). The author has given priority to simple formulations using easily available Oushadhas (medicines) the effect of which are established by the author himself through his clinical experience. Some diseases mentioned in ancient treatises are not found in this text whereas some new diseases are included. As the book found worth study, this paper aims at an overview on the treatise Hitopadesa Vaidyaka.
\end{abstract}

\section{INTRODUCTION}

Ayurveda, the science of life is one of the traditional medical systems which have a holistic approach towards life. In ancient times the knowledge of this system were passed orally from teachers to students. In course of time scholars began to record their knowledge in the form of treatise such as Charaka Samhita, Susruta Samhita etc. In the course of time many Acharyas composed their own treatises on the basis of knowledge they acquired as well as their own observations and experiences.

\section{Access this article online}



Madhavanidana, Sarangadhara Samhita, Bhavaprakasa, Kasyapa Samhita etc., are such contributions by various scholars.

The treasures of traditional knowledge in the field of medicine are still not exhaustively explored. The ancient knowledge is updating by new physicians through the observations they made in relation with changes in Kala, Desa, availability of medicines, newly emerging diseases etc. So it is necessary to explore such treasures of knowledge.

Hitopadesa vaidyaka is a work on Ayurveda which give emphasis on the diagnosis of disease as well as treatment through simple medicinal formulations. Author of the book was a Jainacharya Sri Sreekanthasuri and he has written the book in an easy style so that readers can easily understand. Hitopades vaidyaka starts with Ashtasthana pareeksha where Nadi pareeksha is given utmost importance. The book provides description of Jvara etc., diseases with brief description on Lakshana and detailed description on Chikitsa. The author has given priority to simple 
formulations using easily available Oushadhas the effect of which are established by the author himself through his clinical experience.

\section{About the Author ${ }^{[1]}$}

The author of the text Hitopadesa Vaidyaka is Sri Sreekanthasuri. $\mathrm{He}$ is also known as Sreekanthapanidatta. Variants are Srikanthasambhu, Srikanthasivapanidatta and Sivapanidatta. He was a Jain monk, as is apparent from the Mangala sloka addressing to Aditeerthankara Sree Rishabhadeva, and a number of references to Jainism. Also he was designated as Paramajainacharya in the treatise. He was resided in Siddhapura village and Dhulegamv. Srikanthasuri is said to have lived in the period A.D 1445- 1545. Quotations from Hitopadesa are found in some works from the eighteenth century. One of the MSS dates from 1734/35. He is quoted in Prayogamrita and Srikanthasambhu in the Sarangadharapaddhati.

Some of the medical works by his hand include Bhishagbhushana and Yogapradeepa. According to some scholars he is the author of the book Yogaratnavali. But according to G. J. Meulenbeld, he is probably different from the author of the Yogaratnavali, who was a Hindu.

\section{About The Book}

The treatise is written in Sanskrit language in verse form. A Hindi Teeka written by Sri Harisankaratmaja Sankaralala, a physician native of Muradabad, is also available. It was published by Khemaraja Sreekrishnadasa, Mumbai. Hitopadesa is quoted in Ananta's Pratapakalpadruma, Vachaka Deepachandra's Langhana pathya nirnaya and Meghamuni's Meghavinoda.

The word Hitopadesa is a Sanskrit compound consisting of two terms 'Hita' which means good or friendly and 'Upadesa' which means instructions. As the name indicates the book contains good instructions to the Vaidyas aiming at the Hita i.e., well being of the people who suffered from diseases. So the book is named Hitopadesa Vaidyaka. The colophon at the end of $10^{\text {th }}$ chapter suggests a synonym Vaidyakasara samgraha.

The book is written in an easy style and in verse form so that the readers can easily understand the content. The book is praised for its poetic quality and medical utility, at the end that the book is possessed with Vimalakavyagunas like a necklace made of beautiful and pure pearls which shines in the neck of Panditas. The author has arranged the description of diseases in an order different from other Ayurvedic treatises. The treatise consists of about 1050 verses, arranged in 10 chapters.

\section{Chapters of the Book}

The chapters are called Samuddesa and there are 10 Samuddesa in total. Name of the chapters is tabulated in table 1.

Table 1: Name of chapters in Hitopadesa Vaidyaka

\begin{tabular}{|c|l|}
\hline Chapter number & Name of Chapter \\
\hline 1 & Nadipareekshadyadhikara \\
\hline 2 & Jvaradyadhikara \\
\hline 3 & Sirorogadyadhikara \\
\hline 4 & Netrarogadhikara \\
\hline 5 & Hridayarogadhikara \\
\hline 6 & Udararogadhikara \\
\hline 7 & $\begin{array}{l}\text { Kuranda-arso-atisara } \\
\text { rogadyadhikara }\end{array}$ \\
\hline 8 & Lutabhagandharadyadhikara \\
\hline 9 & Kushtaroga vatarogaahikara \\
\hline 10 & Balarogadyadhikara \\
\hline
\end{tabular}

First chapter: Deals with Ashtasthana pareeksha, but describes in detail five forms of Pareeksha only. More than half of the chapter is devoted to Nadipareeksha. The wrist is said to be the chief place for Nadipareeksha, but information on particular groups of diseases can be collected by feeling the pulse elsewhere. The pulse of feet and ankle indicates disorders of lower part of body. The Nadi of umbilical region called Bodhini, informs about diseases like Udara, Arsa and Bhagandhara etc. Brahmarandhra is also mentioned among the places to be examined. Twenty four Nadis are said to transport the three Doshas; Ida, Pingala and Sushumna conveys Vata, Pitta and Kapha respectively.

Detailed description of Nadipareeksha including its importance, benefit, contraindications, Nadipareeksha vidhi, Sthana and Kala of Vatadi nadis, Gati of Nadi in vitiation of Ekadosha, Dvidosha, Sannipata and Vatarakta, Asadhyanadi Lakshana, features of Nadi indicative of time of death, Ayu pramana based on Sooryamandala, features of Nadi of Sadhyarogi and importance of Nadijnana are described.

The description on Mootrapareeksha includes Mootragrahana samaya (time for collection of urine), Mootragrahana vidhi (method of urine collection), Mootrapareeksha vidhi (method of examination of urine), features of Mootra in conditions with predominance of Vata, Pitta, Kapha, Vatapitta, Vatakapha, Pittakapha, Tailabindu pareeksha including description of shapes attained by Tailabindu in various conditions and Bhasma pareeksha, Mootradhara pareeksha and Nirdosha mootralakahana. Also there is description of Varna of Mootra in conditions like 
Vatadi jvara, Vatarakta, Atisara, Jalodara, Pittadhikya etc.

Netrapareeksha, Mukhapareeksha and Jihvapareeksha are also described with features in Vatakopa, Pittakopa, Kaphakopa, Dvidosha and Tridosha kopa.

Second Chapter: Jvaradyadhikara deals with importance of Hetvadi pareeksha, functions of Vata, Pitta and Kaphadosha, Jvarotpatti and its 8 types viz. Vatika, Paittika, Kaphaja, Sannipathaja, Abhicharaja, Devaprakopaja, Grahakopaja and Manasa, other causes of Jvara like Soka, Krodha, Moha etc., are dealt along with Lakshana of Amajvara, Malajvara, Pakvajvara and Jvaramukti. First line of treatment in Jvara is mentioned as Nivatasevana, Sveda, Langhana, Ushnavaripanam and then Yusha. Specific Lakshana and Chikitsa of Vata, Pitta, Kapha, Vatapitta, Vatakapha, Pittakapha and Sannipatha javara are described with simple Yogas including Samjnajanaka Kriyas for Jvaramurchita, Grahabhootadivyadhihara nasya, Grahajvarahara dhoopa, Lasunadi anjana.

Jvaratisara chikitsa and Pathya and Apathya in Jvara and Sooladi roga, Trividha matra of Oushadhi i.e., Sreshta (1 Palam), Madhya (1/2 Palam) and Adhama (1/4 Palam), quantity of water to be taken in Kvatha preparation according to type of Oushadha are also described.

Third Chapter: Sirorogadyadhikara deals with treatment of Siroroga, Karnaroga, Nasaroga, Mukharoga, Dantaroga, Oshtaroga and Galaroga. Trishna chikitsa also included in this chapter using various Panayogas, Masthaka lepa, Lehayoga, water heated with Taptaloha which is mixed with Laja, Kshoudra and Sita after cooling, Gulika for Mukhadharana, Nasya yoga etc.

Fourth Chapter: Netrarogadhikara deals with Lakshana, Samanya and Visesha chikitsa of various Netrarogas of Vatika, Paittika, Kaphaja and Sannipathika types. Use of Parada for Anjana and Kshalana with water while chanting Arunamantra is advised. Treatment for Kamala is included here with some formulations for Anjana, Nasya and Pana. An Anjanayoga named Chandrodayavati is mentioned as Drishti prasadini when used as Anjana. Treatment for Nidra and Tandra using Anjana and Nasya is also mentioned.

Fifth Chapter: Hridayarogadhikara deals with the treatment of seven Hridayaroga (seven diseases of Hridaya pradesa) viz. Kasa, Hridroga, Soola, Udhvasiroga, Kshaya, Gulma and Hikka. A Ghrita yoga named Vidangadi ghrita along with its Pakavidhi (method of preparation) is mentioned for Vatagulma.

Sixth Chapter: Udararogadhikara deals with six Udararogas viz. Chardi, Jalodaram, Svasam, Soolam, Pleeha and Ahijambuka and six diseases of genitourinary system viz. Prameha, Mootrakrichra,
Nriroga (Upadamsa), Mootrasarkara, Mootrarodha and Ushnavata along with their treatment. Various formulations Kriminasanayogas in the form of Kvatha, Churna, Lehya, Polika (preparation of medicated Rotti like food article) etc are described. Treatment for Prishtasoola, Kukshisoola, Katisoola, Nabhisoola and Nalagulma are described.

Seventh Chapter: Kuranda arso atisararogady adhikara contains description of Kurandaroga, Arsas, Atisara, Grahani and five types of Padarogas viz. Sleepada, Ringinivata, Urusthambha, Vicharchika and Turvala along with their treatment.

Eighth Chapter: It is on Lutabhagandharadyadhikara. Here four Doshic groups of Luta are distinguished, subdivided into a number of types, each one having its own name and location. Lutavishahara prayogas like Agastipatra niryasa lepa etc and Asadhya luta lakshana are mentioned. Bhagandara roga is described along with Lakshana and Chikitsa including various simple Lepayogas. A disease called Jvalagardabha is described with a number of types according to its location like Goura on the back, Pingala on the head, Krishnasya in the cardiac region etc.

Ninth Chapter: Kushtaroga vatarogaahikara deals with 6 types of main Kushtarogas - Udumbara, Svitra, Vipadi, Gajacharma, Mandala, Charmadala and 18 types of Kushta viz. Kapalam, Kakanam, Svitram, Mandalam, Kitibham, Alasam, Dadru, Charmadalam, Pama, Pundareekam, Satavranam, Visphotam, Udumabaram, Sidhma, Charmakushtam, Vipadika, Rishyajihva and Vicharchika along with their Lakshana and Chikitsa. Vatadi dosha and papa are mentioned as Nidana of Kushtarogas.

A Kvatha prayoga named as Chintamani prayoga is described for Kushta chikitsa as follows; Kvatha is prepared with Siva, Pathya, Vrisha, Nimbavalkala, Vyadhikhataka, Patola, Patala, Raji, Salmali, Chitraka, Amrita, Tumburu, Katuki, Danti, Karanja, Vibheetaki, Bharngi and Varuna. It is to be administered for 21 days at morning and then have Salitakra bhojana. Day sleep should be avoided. This will cure Sarvakushta.

Ten kinds of Vata namely Prana, Apana, Samana, Udana, Vyana, Dhananjaya, Krikara, Devadatta, Naga and Koorma are distinguished and their actions described. Ten Nadis, in which these ten kinds are supposed to circulate, are mentioned by name; Ida, Pingala, Sushumna, Hastijihvika, Alammukha, Yasa, Musa, Kandhari, Sinkhini and Kuhu. Symptoms of Prakupita vayu are described prior to the description of treatment. A Taila named Vriddhavatari taila is indicated for Pana as well as Abhyanga for various Vatarogas.

Tenth Chapter: Is named as Balarogadyadhikara. This chapter deals with treatment of Balaroga, Streeroga, Nadivrana, Visarpa, Raktapitta, Panduroga, Arbuda, 
Granthi, Visha etc. Section on Balaroga chikitsa contains many simple formulations for the treatment of Jvara, Chardi, Kasa, Grahadosha etc in Bala. Section on Streeroga chikitsa contains various Oushadhayogas to be used in Streerogas like Raktapradara etc and for preconceptional, antenatal care, care during labour and after labour. Some formulations to stimulate Agni are also included in this chapter.

\section{Salient Features}

> Method of diagnosis through Ashtasthana pareeksha is dealt in the first chapter, but five forms of Pareeksha only are described in detail. More than half of the chapter is devoted to Nadipareeksha. Brahmarandhra is also mentioned among the places to be examined for Nadi Pareeksha. Twenty four Nadis are said to transport the three Doshas. Ida, Pingala and Sushumna convey Vata, Pitta and Kapha respectively. Characteristics of Nadi of the Doshas when normal and abnormal states, characteristics of Nadi in particular diseases, signs indicating incurability or death within a specified period of time etc are also mentioned.

Ayupramana based on the characteristic of Sooryamandala seen by the patient is described.

> Mootrapareeksha including characteristic of urine in disorders of Doshas are described, the examination by means of a drop of oil i.e., Tailabindu pareeksha, the characteristic of urine in a series of diseases and the prognostic meaning of the form assumed by the drop of oil. Netrapareeksha, Mukhapareeksha and Jihvapareeksha are also dealt with, but verses on Mala, Sabda and Sparasa pareeksha are absent.

> Seven disorders located in the cardiac region viz. Kasa, Soola, Udhvasi, Kshayaroga, Gulma, Hikka, and Hridroga are described under the heading Hridroga.

> Six abdominal diseases viz. Chardi, Udara, Svasa, Pleeha, particular forms of Sula and Ahijambuka are described as Udararogas.

> Six disorders of the urinary tract viz., Prameha, Mootrakrichra, Nararoga, Mootrasarkara, Mootrarodha and Ushnavata are described.

$>$ Five diseases of legs (Padaroga) viz., Sleepada, Ringinivata, Urusthambha, Vicharchika and Turvala are described in $7^{\text {th }}$ chapter.

The verses on Luta are interesting. Four Doshic groups of Luta are distinguished as Vatika, Paittika, Kaphaja and Sannipathika, and subdivided into a number of types, each one having its own name and location.

The disease called Jvalagardabha is also divided into a number of types according to its location. these types are; Goura on the back, Pingala on the head, Krishnasya in the cardiac region, Soumyadrish on the nose, Kalahapriya on the legs, Vijaya on the hands, Kumbhakarna on the buttocks, Kapila on the lateral parts of abdomen, Priyadarsana on the chest.

$>$ The group of diseases called Kushta is divided into six or the usual eighteen types.

> Ten kinds of Vata are distinguished and their actions described. Ten Nadis, in which these ten kinds are supposed to circulate, are mentioned by name; Ida, Pingala, Sushumna, Hastijihvika, Alammukha, Yasa, Musa, kandhari, Sinkhini, and Kuhu.

$>$ The Tridosha theory has a very important place, as appears from the description of the Doshic types of numerous diseases. Some generally recognized diseases are not mentioned at all, e.g. Arochaka, Murcha, Panatyaya, Amavata, Udavarta, Anaha, Medoroga, Vidradhi, Bhagna, Sitapitta, Amlapitta and the majority of Kshudrarogas. Diseases like Somaroga, Phiranga Roga etc are absent as well. The symptoms of an illness are usually described prior to its treatment.

$>$ The recipes are simple for the larger part. A few only are more complicated and provided with names eg. Chandrodaya vati, Vriddhavatari taila etc.

Use of Rasoushadha is limited which include mercury, Gandhaka, Kajjaliprayoga, Haritala, Manasila, Loha, Kaseesa etc.

$>$ Sources of knowledge on the basis of which the treatise was composed are hardly mentioned; Srikantha refers to Sivamata (1.80) and to Sambhudeva (8.30).

- The Hitopades presents a large number of noteworthy features in the field of nosology.

$>$ The following eight types of fever are enumerated, caused by Vata, Pitta, Kapha, Sannipata, Abhichara, Grahakopa and an eighth one of mental origin. Two irregular fevers are added to the usually mentioned series, a type of recurring every fifth (Panchamaka) and one recurring every sixth day (Shashtadinodbhava).

$>$ Names of diseases occurring in this work only are Ahijambuka, Bala, Chalika, Dheemada, Govara, Khasara, Nalagulma, Turvala and Udhvasi.

$>$ The term Ghoormi is employed as a synonym of Tandra. Katigridhra may be a synonym of Katisoola.

$>$ The term Ringinivata denotes the disorders commonly known as Gridhrasi.

The disorder called Ushnavata, usually regarded as a variety of Mootraghata is separately mentioned.

> Kamala Chikitsa using Anjana, Nasya and Pana Yogas is included under Netraroga adhikara. Treatment of Nidra and Tandra are also included in Netraroga adhikara. The term Ghoormi is employed as a synonym of Tandra. 


\section{CONCLUSION}

Hitopadesa Vaidyaka is also known as Vaidyakasarasamgraha and is an Ayurveda treatise which emphasis on diagnosis and treatment of various diseases. The author of the treatise, Sri Sreekantasuri was a Jain monk. Diagnosis of diseases through Ashtasthana pareeksha is explained in this treatise where Nadi pareeksha is given utmost importance. Application of Nadipareeksha in diagnosis as well in ascertaining the prognosis is described in detail.

The author has given more emphasis on the practical aspect rather than explanation of theories. The text provides knowledge regarding a lot of simple medicinal preparations using easily available Dravyas which are useful in OP level treatment. This shows the knowledge and experience of the author in identification of medicinal plants as well as in treatment of various diseases. Some diseases mentioned in ancient treatises are not found in this text whereas some new diseases are included such as Ahijambuka, Bala, Chalika, Dheemada, Govara, Khasara, Nalagulma, Turvala, and Udhvasi. Most of the diseases are classified on the basis of involvement Doshas and described with their differential features. Mainly Samana oushadhas in the form of Swarasa, Churna, Lepa, Kvatha etc are described. Nasya and Anjana prayogas are also advised in various conditions. Limited number of Rasaoushadha prayoga (such as Parada, Gandhaka, Kaseesa, Haritala, Manasila etc.) is available in this treatise.

So Hitopadesa Vaidyaka is a treatise which can be considered as a hand book for physician which if explored, will be beneficial for safe and effective management through simple formulations.

\section{REFERENCES}

1. G. Jan Meulenbeld, A history of Indian Medical Literature volume II A, Groningen Oriental Studies, 2000, P 474

\section{Cite this article as:}

Ujitha Kuttan K, Braivin Camly R. An Overview on Hitopadesa Vaidyaka International Journal of Ayurveda and Pharma Research. 2021;9(11):47-51.

https://doi.org/10.47070/ijapr.v9i11.2103

Source of support: Nil, Conflict of interest: None Declared

\section{*Address for correspondence} Dr. Ujitha Kuttan K

M D Scholar,

Department of Samhita Samskrita

and Siddhanta,

Govt. Ayurveda College,

Thiruvananthapuram.

Email : drujithaaneesh@gmail.com

Mobile number: 9447314232

Disclaimer: IJAPR is solely owned by Mahadev Publications - dedicated to publish quality research, while every effort has been taken to verify the accuracy of the content published in our Journal. IJAPR cannot accept any responsibility or liability for the articles content which are published. The views expressed in articles by our contributing authors are not necessarily those of IJAPR editor or editorial board members. 